\title{
Knowledge Index of Farmers about Animal Feed Technologies during Various Training Programmes at Veterinary Varsity in Punjab, India
}

\author{
Aparna $^{1 *}$, Suresh Kumar Kansal ${ }^{1}$, Harish KumarVerma ${ }^{2}$, Jaspal Singh Hundal ${ }^{3}$, \\ Parminder Singh ${ }^{1}$ and Jaswinder Singh ${ }^{1}$
}

${ }^{1}$ Department of Veterinary and Animal Husbandry Extension Education, ${ }^{3}$ Department of Animal Nutrition, College of Veterinary Sciences, Guru Angad Dev Veterinary and Animal Sciences University, Ludhiana (Punjab), India

${ }^{2}$ Directorate of Extension Education, Guru Angad Dev Veterinary and Animal Sciences University Ludhiana (Punjab), India

*Corresponding author

\begin{abstract}
A B S T R A C T
Veterinary Universities conduct vocational training courses to impart knowledge to farmers. In order to convert knowledge into practice it needs to be retained for an extended period of time. The present study evaluated the knowledge index (KI) of farmers about animal feed technologies after training course at Guru Angad Dev Veterinary and Animal Sciences University (GADVASU), Ludhiana

\section{Key w ords}

Knowledge retention,

Evaluation, Awareness,

Knowledge Index,

Animal feed technologies

Article Info

Accepted:

04 March 2018

Available Online:

10 April 2018 (Punjab). A pre, post and delayed post-test study was conducted on 120 farmers through Knowledge test on Mineral mixture, Urea treatment of wheat straw (UTWS), Uromin lick (UL), Silage making, Hay making, Bypass fat (BF), Bypass Protein (BP), Total mixed ration(TMR), Buffer and Probiotics. In pretest the awareness about the existence of technologies varied between 2.5 and $50.0 \%$ (Probiotics and Silage) which increased to 95.8 and 100\% (Probiotics and MM, UTWS, Silage and BF) in post-test I. In Post-test II awareness decreased and varied between 32.5 and 100\% (Probiotics and MM, UL and Silage) and for Hay, TMR, Buffers and Probiotics downfall was significant. KI for pre-test was 9.72 increased significantly to 75.90 for post-test I and decreased significantly to 40.42 for post-test II $(\mathrm{P}<0.001)$. Overall gain of knowledge was significant. Knowledge score was highest for Silage in all three tests $(1.67,4.45$ and 2.62) followed by Mineral Mixture (0.86, 4.16 and 2.42) in pre, post-test I and II respectively).TMR and Probiotics had the lowest pretest ( 0.20 and 0.21$)$ and post-test I (2.91 and 3.86) and delayed post-test score (1.39 and 1.05). Socio-personal parameters had non-significant correlation with knowledge score. Initial improvement in KI indicates effectiveness of training and high assimilation by farmers and later loss of KI reflects non practice. Adoption overrides the retention of knowledge hence follow ups of training programmes are put forward to ascertain the cause behind adoption and non-adoption.
\end{abstract}

\section{Introduction}

Livestock sector in India is facing the threats of feed deficit due to less allocation of land for forages and huge number of low-producing animals. Though dairy sector is considered minimum input and a resource flexible enterprise but optimum availability of feed and fodder is the prerequisite for its sustenance. Grover and Kumar (2012) reported deficit of $62.76 \%$ for green fodder and more than $30 \%$ for concentrates. Birthal 
and Jha (2005) disclosed that the actual milk yield of bovines is reported to be $26-51 \%$ below the attainable yield under field conditions. In order to exploit full production potential of animals and to cover up the feed deficit improving feeds and feeding practices is the unrivalled choice.

Apart from scarcity of feed and fodder, poor nutrition and nutritional costs are the major production constraints in our system as Kaushal et al., (2007) and Bakshi et al., (2009) reported the underfed and unbalanced nutritional status of animals in undulating plain zone, western plain zone and central plain zone in Punjab. Fodder deficit is localized and seasonal in nature hence Birthal et al., (2006) suggested to promote hay/silage making through community fodder banking.

Singh and Schiere (1994) stressed upon improving the quality of feeds, fibrous crop residues and strategic supplementation like treatment of straws, urea molasses mineral blocks, bypass protein etc. these technologies not only improve the nutritional quality of feed but also help in reducing wastage of feed resources (Bharathidasan et al., 2007) thus increase nutrient digestibility, maintain rumen environment and protect animals from metabolic and deficiency diseases. Some of these technologies are widely known to farmers and some are yet to get mass appeal (Birthal and Taneja, 2006).

Knowledge is the first step towards adoption. Birthal and Rao (2002) reported that lack of information and knowledge to users is the main constraint to large-scale adoption of nutrition technologies. Senthilkumar and Thanaseelaan (2013) and Kasrija (2016) also revealed that "nutritional aspect" was the most needed area for training. Hence extension has to play an effectual role in changing the knowledge, skill and attitude of farmers towards animal feeding innovative technologies through trainings. In order to convert knowledge into practice it needs to be retained for an extended period of time. Hence assessment of knowledge retention may ascertain the cause behind adoption or nonadoption. Keeping these points in view the present study was designed with the following objectives:

To evaluate the Knowledge Index (KI) of farmers about animal feed technologies before the training

Intervention of training course to assess the change in Knowledge Index

To appraise retention of knowledge and its relevance with their Socio Personal parameters

\section{Materials and Methods}

The purpose of this study was to evaluate effect of training intervention on the learners on their knowledge level about animal feed technologies (AFTs) immediately after the intervention and at a gap of six months after the training. The other purpose was to explore possible demographic factors that contribute to the retention of knowledge. Guru Angad Dev Veterinary \& Animal Sciences University (GADVASU), Ludhiana (Punjab) conducts vocational trainings for farmers, hence 120 participants of three vocational training courses on Dairy farming (August 2015August 2016) were purposively selected for the evaluation.

\section{Development of questionnaire}

Ten animal feed technologies Mineral mixture (MM), Urea treatment of wheat straw (UTWS), Uromin lick (UL), Silage making, Hay making, Bypass fat (BF), Bypass protein (BP), Total mixed ration (TMR), Buffer and Probiotics were selected and a knowledge test 
was developed with help from the pertinent literature, personal experience, discussions held with the experts and pilot study conducted in the area of investigation. The questionnaire had three parts:

Information on demographic profile of respondents

Awareness / familiarity percentage assay about AFTs

Knowledge test - multiple choice items' test about AFTs

Total 50 items were there in the knowledge test and each technology was tested through five multiple choice items. Each item had total four options and only one correct option.

\section{Experimental Design}

Study was conducted in Four phases. The first phase was pre-test (on day 1 of training) respondents were assessed about their demographic profile by interview method, assayed about their awareness/ familiarity and evaluated for their knowledge level through test method. Second phase was the intervention /training for 15days and special classes were organised during the training on the technologies under study.

Third phase was Post-test I (immediately after the intervention) in which their awareness percentage and knowledge level was tested with same questionnaire. In fourth phase i.e. Post-test II the same respondents were evaluated again after 6 months of the completion of training. Fourth phase was carried out through post, emails, telephonic contact and personal visits.

\section{Operationalization of variables}

Awareness percentage and knowledge scores were the dependent variable and age, education, land holding, herd size, experience, social participation and entrepreneurship level of dairy farming were the independent variables. Awareness/ familiarity percentage assay was answered by respondents as 'Yes' or 'NO'. Assay was evaluated in a way that score 1 was given to the candidate who answered 'YES' to the awareness about the existence of the technology and 0 if the answer was 'NO'. Maximum possible score for awareness percentage assay was 10 and minimum possible score was 0 . Knowledge test was evaluated in a way that each right answer was scored as one and each wrong answer was scored 0 . The sum of score was taken as knowledge score. Maximum score possible was 50 and minimum was 0 .

The knowledge index was calculated as follows:

$$
\text { KI = } \frac{\text { Score obtained }}{\text { Total Obtainable score }}
$$

\section{Statistical analysis}

The data was analysed through suitable statistical tools like frequency, percentage, correlation, ANOVA, t- test and Chi square test by SPSS version 22.0.

\section{Results and Discussion}

Figure 1 depicts the demographic profile of respondents the respondents were the trainees of training course on Dairy farming at GADVASU, Ludhiana. A large section of respondents $(68.3 \%)$ belonged to $18-30$ years age category. $18.3 \%$ respondents belonged to category of 31-40 years and least number $(13.3 \%)$ belonged to the category of 41 years and above with a mean value of 29.04 years. Ingle and Kubde (1995) also observed that relatively higher proportion $\mathrm{KVK}$ trainees were young in age i.e. up to 25 years age 
$(30.30 \%)$ and in 26 to 35 years age group (33.33\%) group.

Matric was the minimum qualification requirement for training and $37.5 \%$ respondents had matric as their educational qualification. Maximum percentage (43.3\%) had higher secondary as their educational profile. Among the rest, $12.5 \%$ respondents were graduates and $6.7 \%$ were postgraduates. Average level of education was 11.95 i.e. higher secondary. A study on participants of training in GADVASU by Hundal et al., (2016) also revealed that majority of respondents i.e. $17.6 \%, 31.2 \%$ and $42.4 \%$ respondents were educated upto middle, matric and senior secondary level, respectively whereas $8.8 \%$ trainees were graduates.

Education and age profile indicates that after acquiring the educational qualification of higher secondary or even after matric young farmers tend to acquire expertise in the technical knowledge in the enterprise of dairy farming in order to adopt it as a profession thrivingly.

$65 \%$ respondents had a land holding of 1-5 acres and $15 \%$ had holding of more than 10 acres i.e. about $85 \%$ respondents had the holding of less than 10 acres. Average land holding was 5.97 acres. Desai (1996) also observed the similar level of land holding as majority of KVK trainees $(60.10 \%)$ owned 1 4 ha of land holding. Maroo (2005) also found that $66 \%$ respondents had up to 5 acres of land, 29.00 per cent of respondents possessed 5.01 to 10 acres of land and only 4.16 per cent of them had above 10 acres of land

Herd size data indicated that $80 \%$ respondents had herd size of up to ten and among those $55.8 \%$ had herd size of upto 5 animals, indicating a non-commercial domestic type of enterprise. Their initiative to get hands on training reflects their urge to improve the level of entrepreneurship. 20\% respondents had herd size larger than 10 i.e. they already are in commercial gait and training may further take them to higher level of adoption of innovations. Mean herd size came out to be 6.8 animals. Lokhande (2009)in their study reported that most of the respondents $(40.83 \%)$ were having medium herd-size of 7 9 animals, 36.67 per cent were in small herdsize category of 4-6 animals, 15.83 per cent were having herd-size of more than 10 animals and only 6.67 per cent of respondents were having marginal herd-size of less than 3 animals.

Majority being of young age group, their experience in dairy farming was also of short duration, $70.8 \%$ respondents belong to the category of $1-5$ years' experience, $14.2 \%$ belonged to 5-10 years category and merely $15.0 \%$ respondents had more than 10 years' experience. Average experience in dairy farming was 5.11 years. Lower experience profile of respondents corresponds to their age profile. Kiptot et al., (2015) also conducted a study on awareness about livestock feeding innovations concluded that $57 \%$ respondents had experience of up to $10 \mathrm{yrs}$.

Comprehensively the sample population was constituted by young respondents with higher secondary education, small herd size and low experience.

Table 1 portrays the comparative analysis of mean familiarity percentage of respondents across Pre-test, Post-test I and Post-test II and statistical significance of difference between the tests and individual technologies as well (Chi square, Cocharan Q test). There was a significant change in awareness level from Pretest to Post-test I $(\mathrm{P}<0.001)$. The drift became different between posttest I and II and it varied for different technologies as well. The data indicates that during pre-test percentage of awareness was highest for 
mineral mixture and silage making as they were known to the $41.7 \%$ and $50.0 \%$ respondents respectively. This could be an indicator for better adoption status of these two technologies as Sathiadas et al., (2001) reported that in 50\% cases under study lack of knowledge was reason behind non adoption.

Familiarity of other technologies varied between 2.5-19.2 \%. Silage and mineral mixture were followed by bypass fat $(19.2 \%)$, bypass protein (17.5\%), UTWS (15.0\%), UL (13.3\%), hay (12.5\%), buffers (9.2\%), TMR (7.5\%) and the last was the Probiotics (2.5\%). The percentage of awareness about these technologies rose significantly to $100 \%$ in case of MM, UL, silage and Bypass fat in Post-test I. For other technologies it reached 99.2\% for bypass protein, $98.3 \%$ for UTWS, $97.5 \%$ for TMR, $96.7 \%$ for buffers and Hay and $95.8 \%$ for probiotics and this rise was statistically significant $(\mathrm{P}<0.001)$. However the drift could not be maintained in post-test II as only MM and silage retained their 100\% familiarity and UL and bypass fat lost their level of familiarity from $100 \%$ to 96.7 and 94.2\% respectively but without change in statistical significance from post-test I. Maximum gain and loss of familiarity was recorded for probiotics as the percentage of awareness raised from $2.5 \%$ to $95.8 \%$ in posttest I and then fell significantly to $32.5 \%$ in post-test II.

Hay TMR and buffers also lost the awareness significantly in post-test II from 96.7, 97.5 and 96.7 to $66.7,81.7$ and $60.8 \%$ respectively. Bypass protein's percentage of familiarity fell from 99.2 to $92.5 \%$ but, non-significantly.

The table infers that awareness about all the technologies improved significantly in posttest I but in Posttest II it sank significantly for hay, TMR, Buffers and Probiotics. Kiptot et al., 2015 also assessed the awareness of respondents about feeding practices and reported similar level of awareness as in pretest in present study. They found that the awareness level varied from 1.7-40.9\%. Awareness about silage was maximum i.e., $40.9 \%$ and for hay it was $24.9 \%$. Lowest awareness i.e., $1.7 \%$ was noted for homemade concentrates.

Vidya et al., (2010) and Hundal et al., (2016) notified the significantly raised level of awareness perceived by farmers about feeding, reproduction and disease management after an intervention on learning.

Table 2 is delineating the mean test score of respondents for each technology in all the three repeated measure tests. A mixed ANOVA was used to test for significance of difference between the related repeated measure groups across time. Silage had the highest mean score in pre-test and the other two post-tests with statistically significant difference between all the three at $0.01 \%$ level of significance. While comparing the score for silage between the tests pretest had the lowest score $1.67 / 5$ and score increased to $4.45 / 5$ in post-test I but during post-test II the score fell to $2.62 / 5$. This indicated gain in knowledge level of respondents after attending the training but, a gap of six months probably led to forgetting due to not reading about the skill or its non-usage or both (John 1982).

Second highest score in pretest was recorded for mineral mixture i.e., $0.86 / 5$ which increased to $4.16 / 5$ in post-test I and reduced to 2.42 in post-test II. In pre-test the mean knowledge score for UL was found to be the third highest one (0.63) followed by UTWS (0.46) buffers $(0.40)$, hay and Bypass protein (0.33), bypass fat (0.29), probiotics $(0.21)$ and last being the TMR (0.20). Overall knowledge score was lowest in pre-test followed by posttest II and I. 
Table.1 Frequency of farmer's awareness/familiarity towards different AFTs over Pre-test, Posttest-I and Post-test-II in non-formal education programme

\begin{tabular}{|c|c|c|c|c|c|}
\hline \multirow{2}{*}{$\begin{array}{l}\text { Name of } \\
\text { technology }\end{array}$} & \multicolumn{3}{|c|}{ Farmer's awareness/familiarity $\mathbf{N}=\mathbf{1 2 0}$} & \multirow{2}{*}{$\begin{array}{c}\text { Cochran's } \\
Q \text { test }\end{array}$} & \multirow[t]{2}{*}{ p-value } \\
\hline & Pre-test & Post-test I & Post-test II & & \\
\hline $\begin{array}{l}\text { Mineral } \\
\text { mixture }\end{array}$ & $50^{\mathrm{a}}(41.7)$ & $120^{\mathrm{b}}(100)$ & $120^{\mathrm{b}}(100)$ & 140.00 & 0.000 \\
\hline UTWS & $18^{\mathrm{a}}(15.0)$ & $118^{\mathrm{b}}(98.3)$ & $120^{\mathrm{b}}(100)$ & 198.13 & 0.000 \\
\hline$\overline{\mathrm{UL}}$ & $16^{\mathrm{a}}(13.3)$ & $120^{b}(100)$ & $116^{\mathrm{b}}(96.7)$ & 198.40 & 0.000 \\
\hline Silage & $60^{\mathrm{a}}(50.0)$ & $120^{b}(100)$ & $120^{\mathrm{b}}(100)$ & 120.00 & 0.000 \\
\hline Hay & $15^{\mathrm{a}}(12.5)$ & $116^{c}(96.7)$ & $80^{b}(66.7)$ & 145.57 & 0.000 \\
\hline $\mathrm{BF}$ & $23^{\mathrm{a}}(19.2)$ & $120^{\mathrm{b}}(100)$ & $113^{b}(94.2)$ & 179.16 & 0.000 \\
\hline$\overline{\text { BP }}$ & $21^{\mathrm{a}}(17.5)$ & $119^{b}(99.2)$ & $111^{b}(92.5)$ & 177.68 & 0.000 \\
\hline TMR & $9^{a}(7.5)$ & $117^{\mathrm{c}}(97.5)$ & $98^{\mathrm{b}}(81.7)$ & 179.69 & 0.000 \\
\hline Buffer & $11^{\mathrm{a}}(9.2)$ & $116^{\mathrm{c}}(96.7)$ & $73^{b}(60.8)$ & 147.95 & 0.000 \\
\hline Probiotics & $3^{\mathrm{a}}(2.5)$ & $115^{\mathrm{c}}(95.8)$ & $39^{\mathrm{b}}(32.5)$ & 169.10 & 0.000 \\
\hline
\end{tabular}

Figures in parenthesis indicate the percentage

Table.2 Technology wise knowledge score of farmers towards different Animal feed technologies over Pre-test, Posttest-I and Post-test-II

\begin{tabular}{|c|c|c|c|c|c|}
\hline \multirow[t]{2}{*}{ Name of technology } & \multicolumn{3}{|c|}{ Mean Knowledge test score (out of 5) } & \multirow[t]{2}{*}{ PSE } & \multirow[t]{2}{*}{ P-value } \\
\hline & Pre-test & Post-test I & Post-test II & & \\
\hline Mineral mixture ${ }^{* * *}$ & $0.86^{\mathrm{a}}$ & $4.16^{c}$ & $2.42^{\mathrm{b}}$ & 0.091 & 0.000 \\
\hline UTWS*** & $0.46^{\mathrm{a}}$ & $3.98^{c}$ & $2.39^{b}$ & 0.092 & 0.000 \\
\hline UL*** & $0.63^{a}$ & $4.22^{c}$ & $2.14^{\mathrm{b}}$ & 0.096 & 0.000 \\
\hline Silage $* * *$ & $1.67^{\mathrm{a}}$ & $4.45^{\mathrm{c}}$ & $2.62^{b}$ & 0.089 & 0.000 \\
\hline Hay ** & $0.33^{\mathrm{a}}$ & $3.41^{\mathrm{c}}$ & $1.75^{b}$ & 0.083 & 0.000 \\
\hline Bypass fat $* * * *$ & $0.29^{\mathrm{a}}$ & $3.52^{c}$ & $1.88^{\mathrm{b}}$ & 0.084 & 0.000 \\
\hline Bypass protein*** & $0.33^{\mathrm{a}}$ & $3.57^{\mathrm{c}}$ & $2.13^{b}$ & 0.085 & 0.000 \\
\hline TMR*** & $0.20^{\mathrm{a}}$ & $2.91^{\mathrm{c}}$ & $1.39^{b}$ & 0.077 & 0.000 \\
\hline Buffer $* * *$ & $0.40^{\mathrm{a}}$ & $3.88^{\mathrm{c}}$ & $2.44^{b}$ & 0.093 & 0.000 \\
\hline Probiotics*** & $0.21^{\mathrm{a}}$ & $3.86^{\mathrm{c}}$ & $1.05^{b}$ & 0.099 & 0.000 \\
\hline
\end{tabular}

Table.3 Knowledge Index of farmers in Pretest, Post-test-I and Post-test-II

\begin{tabular}{|l|c|c|c|}
\hline Test & Knowledge Index & Minimum score & Maximum score \\
\hline Pretest & $9.72^{\mathrm{a}}$ & 0 & 22 \\
\hline Post-test-I & $75.90^{\mathrm{c}}$ & 24 & 47 \\
\hline Post-test-JI & $40.42^{\mathrm{b}}$ & 9 & 35 \\
\hline PSE & 0.756 & & \\
\hline P Value & 0.000 & & \\
\hline
\end{tabular}


Table.4 Correlation of independent variables with knowledge level, gain in knowledge and retention of knowledge in non-formal education programme

\begin{tabular}{|l|c|c|c|c|c|c|}
\hline \multicolumn{1}{|c|}{ Variable } & Pretest & Post-test I & Post-test II & $\begin{array}{c}\text { Pre- Post- } \\
\text { test I }\end{array}$ & $\begin{array}{c}\text { Pre- Post- } \\
\text { test II }\end{array}$ & $\begin{array}{c}\text { Post-test I- } \\
\text { II }\end{array}$ \\
\hline Age & -0.034 & 0.006 & -0.058 & 0.028 & -0.034 & 0.059 \\
\hline Education & 0.084 & 0.127 & 0.025 & 0.020 & -0.012 & 0.028 \\
\hline Land holding & 0.127 & 0.104 & 0.074 & 0.007 & 0.020 & -0.020 \\
\hline Herd size & 0.160 & -0.116 & 0.003 & -0.187 & 0.059 & -0.050 \\
\hline Experience & -6.123 & 0.049 & 0.038 & 0.119 & 0.078 & -0.017 \\
\hline
\end{tabular}

Fig.1 Mean demographic profile of respondents

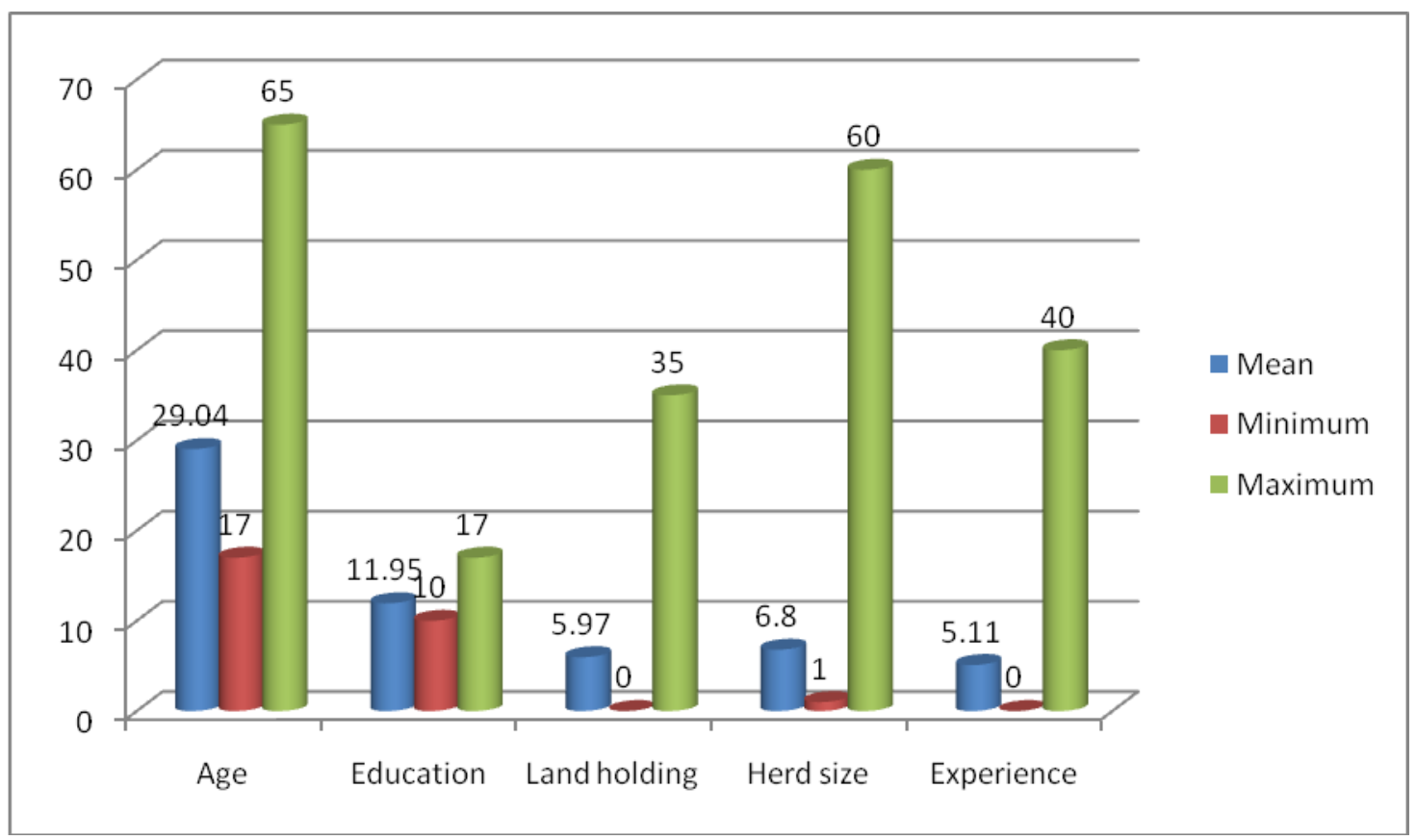

Analogous trend was recorded for all other technologies as well. Knowledge score of UTWS increased from 0.46 to 3.98 and came down to 2.39 in pre post-test I and II respectively. Score for UL increased to 4.22 from 0.63 and fell to 2.14 in post-test I pretest and post-test II respectively. Correspondingly knowledge score revealed a trend of $0.33,3.41$ and 1.75 for Hay, 0.29, 3.52 and 1.88 for Bypass fat, 0.33, 3.57 and 2.13 for Bypass Protein and 0.40, 3.88 and 2.44 for Buffers Among all other technologies TMR and Probiotics had the lowest pretest and posttest score i.e knowledge of respondents was lowest for probiotics and TMR (0.20 and 0.21) which soared to 2.91 and 3.86 in post-test I and sank to 1.39 and 1.05 respectively in post-test II. The possible justification may be that TMR and probiotics are emerging techniques. Singh and Prasad (2002) also endorsed this observation by reporting that though several manufacturers are now adding probiotics to their compound feed. The use of probiotics by farmers themselves is negligible due to lack of awareness and prohibitive cost. Costly equipment for TMR and extra costs on Urea based products certainly affect their diffusion. 
They also reported that main reason behind the less adoption of forage conservation, bypass nutrients was lack of knowledge. Limited knowledge of respondents during pre-test was also reported by Nampanya et al., (2010). This was probably correlated with the husbandry practices smallholder farmers, where large ruminants are raised by traditional low-input and output methods (Wilson, 2007). The present study also had $80 \%$ respondents having small herd holding. But MM and Silage had score higher than other technologies which indicates their better adoption even during pre-test. However Singh and Prasad (2002) reported that most of the farmers use mineral mixture but, on advice of a veterinarian, more knowledge may induce them to adopt it as a feed ingredient not a medicine i.e. training intervention will certainly play its role. Chavan et al., (2016) also endorsed this fact. They said that lack of training led to the situation that 96.67 per cent of the respondents had low adoption in fodder treatment which got improved after gain in knowledge. Kumar et al., (2014) reported nearly $43 \%$ improvement in adoption with gain in knowledge after training.

Correspondingly, a significantly elevated knowledge score in present study even six months after the training foresee a better adoption in future. However loss of knowledge after initial gain indicates non adoption because other factors like cost, relative advantage, complexity of technology also play their role in decision making. Kiptot et al., (2015) also recorded that out of the aware population about practices, all did not adopt it. For example for silage $31.5 \%$ and for hay $17.5 \%$ respondents were aware but all did not adopt the techniques due to their labour intensive nature. Dhaka et al., (2017) also concluded the same. Based on RBQ value, they ranked lack of knowledge and awareness as number one constraint but poor credit support, lack of proper communication system, non-availability of desired technology, complexity of practices, high cost of inputs, and lack of conviction also affect adoption.

Table 1 and 2 both portray the significant gain in awareness and knowledge during training and at the same time also depict significant loss of gained awareness and knowledge i.e. lack of cent percent retention after a gap of six months. But ultimately a statistically significant gain in knowledge is there over and above the knowledge level in pretest. Similar trend was reported by Mathailagan and Kumarasan (2015). They conducted a retention study on farmers on different aspects of mastitis and found that during pretest the mean knowledge score varied between $2-38 \%$ which increased to $75-92.5 \%$ in post-test I and Post-test II reflected a downfall 65.75-82.55\%. Nirmala et al., (2016) also found that the mean knowledge score before exposures to multimedia was 26.12, immediately after exposure was 44.84 and 30 days after exposure was 38.70 , i.e. respondents gained considerable knowledge immediately after exposure to the multimedia modules on various dairy farming practices and could retain the knowledge even after 30 days of exposure but partially. Sharma (2016) also evaluated farmers before and after exposure to multimedia module and found gain in knowledge just after intervention and partial loss at a gap of 30 days.

Gain in knowledge reflects high assimilation capacity of farmers and effectiveness of intervention (NFE programme). However the purpose of training is never confined to improvement in awareness and knowledge only, but is to improve the adoption too which needs to be ascertained by follow-ups. Borate et al., (2011) also advocated this fact by stating that it is necessary to organize skill oriented training emphasizing upon the topics about which low knowledge gain was observed after training. 
Table 3 delineates the Knowledge Index of respondents over pre-test, post-test I and II and very well depicts the raised level of knowledge in post-test I over and above the score in pre-test. Difference of scores was analyzed by applying ANOVA. KI in Posttest I was higher by $66.18(9.72$ vs75.90) and difference was found to be statistically significant $(\mathrm{P}<0.001)$. Minimum score also improved from $0 / 50$ to $24 / 50$ and maximum score from $22 / 50$ to $47 / 50$. Table also describes the lowering of $\mathrm{KI}$ in post-test II as compared to post-test I from 75.90 to 40.42.This indicates the partial loss of knowledge / lesser retention of knowledge in respondents. The score in retention test was significantly lower than post-test I but significantly higher than pre-test. Overall from pre-test to post-test II knowledge index improved by 30.70 points. Nirmala et al., 2016 reported similar significant change in level of knowledge of respondents after the intervention.

The change in knowledge index indicates the immense triumph of NFE curriculum at GADVASU, (teaching methods, material and content) but, lack of retention indicates that the knowledge gained was not practiced in the field and reason for that needs to be further probed out. Not only practice but lack of an effective information flow after the training could also be the rationale behind. Yikii (2009) reported that a large gap exists between the attaining of knowledge and its effective application in decision making. The knowledge that is available is sometimes perceived to be theoretical and hypothetical and the end users thus find it difficult to use such knowledge and non-usage leads to forgetting.

Table 4 describes the correlation of independent variables age, education, experience in dairy farming and herd size with knowledge level, gain in knowledge and retention of knowledge in non-formal education programme. It evidently explains that no definite pattern has been observed. Age and experience had negative correlation but non-significant. Education status, herd size and land holding had positive but nonsignificant result. But in post-test I the correlation changed, in case of herd size it became negative but was positive for age, education land holding and experience and all figures were non-significant. During the phase of pre-test-post-test I effect of age turned to be positive and that of herd size significantly negative. During pre-test - posttest II age and education got negatively correlated. In post-test I -II land holding, herd size and experience was negative. Results indicate that since the trainees were being taught at the same platform, by same teachers the effect of independent variables got nullified and what affected the knowledge was their perception and individual assimilation capacity.

Meena et al., (2009) also studied the correlation with knowledge level and found positive but non-significant correlation with age education herd size and negative and nonsignificant with land holding. While in 2012 Meena et al., observed that Respondents' age was positively and significantly correlated with knowledge of respondents and Sasane et al., (2013) reported that knowledge level was negatively correlated with age. Kalsariya et al., (2015) conducted study to evaluate the effect of socioeconomic parameters on knowledge level before and after the training and found that knowledge level before training was correlated with socio-economic characteristics viz. education, unirrigated land, cropping intensity and training received. While only education and training received were correlates after training of improved agricultural technology. Age and farming experience were correlated positively but not significantly. Hundal et al., 2016 reported a 
non-significant effect of Age and education on knowledge level of farmers about goat farming.

Wide variation in results is explained by Toth (2014).While assessing outcomes of learning he reported that differences between students must be taken into consideration not only at the level of intellectual capacities but also with respect to the most different individual characteristics of sensation, perception, thought and learning. Williams et al., (2008) endorsed this thought by adding that in learning the individual behavioral differences i.e. personality traits and cognitive abilities play their role. Behavior analysts emphasize their research focuses on the behavior of individuals rather than on group averages.

To conclude, age and other independent variables may affect the awareness and knowledge during pre-intervention phase but once learners come to a common platform of learning (training) they learn according to their individual assimilation capacity while retention is dependent on practice and information flow.

Intervention of Training improved the knowledge index and scores significantly this designates the training to be effective. The partial loss of knowledge after a time gap stipulated lack of application and information flow. Knowledge not applied or not read or heard again decays over time. Regular, periodic refreshers/follow-ups and feed backs should be instituted to reinforce and retain knowledge and skills.

Retention is achieved by application of skill or knowledge and by reaching farmers in the field orat home. Frequent resonance of messages will impact him. There after farmer to farmer training through tacit and explicit knowledge empowers others to gain an even deeper understanding. This continues over time, spreading messages all over the community and this is what we call as diffusion.

\section{References}

Bakshi, M.P.S., Wadhwa, M., Kaur, K. and Kaur, J. 2009.Nutritional status of animals of western plain zone of Punjab. Indian Journal of Animal Nutrition. 26: 199-203

Bharathidasan, S., Walli, T.K. and Balakrishnan, V. 2007. Feed resources and feeding practices in Tamil nadu and the scope for nutritional interventions for increasing the productivity of dairy animals. Indian Dairyman. 59(6): 3945.

Birthal, P.S. and Jha, A.K. 2005.Economic losses due to various constraints in dairy production in India. Indian journal of Animal Science. 75(12):1470-1475.

Birthal, S. and Taneja, V.K. 2006. In Birthal, P.S., Taneja, V.K. and Thorpe, W. (eds). 2006. Smallholder livestock production in India: Opportunities and challenges. Proceedings of an ICARILRI international workshop held at National Agricultural Science Complex, DPS Marg, Pusa, New Delhi 110 012, India, 31 January-1 February 2006. NCAP (National Centre for Agricultural Economics and Policy Research)ICAR (Indian Council of Agricultural Research), New Delhi, India, and ILRI (International Livestock Research Institute), Nairobi, Kenya. 126 pp 5-64.

Borate, H.V., Mahadik, R.P., Mahadik, S. G., Mane, A.V., Hake, A.D. and Malashe, K.V. 2011. Knowledge Level of the Farmers Trained by DBSKKV, Dapoli An Action Research. Journal of Community Mobilization and Sustainable Development. 6(2): 205208. 
Chavan, S., Deshmukh, D.S., Sawant, M. and Gangane, G.R. 2016. Adoption of scientific feeding practices by buffalo dairy entrepreneurs in peri-urban area. International Journal of Advanced Research. 4(2): 1275-1280.

Desai, G. R. 1996. Impact of block demonstration on participant and nonparticipant farmers of Dharwad district, Karnataka State. M.Sc. (Agri.) Thesis (Unpubl.) University of Agricultural Sciences, Dharwad.

Dhaka, B. L., Meena, G. S., Meena, N. L., Bairwa, R. K. and Nagar, B. L. 2017. Constraints Analysis in Adoption of Improved Dairy Farming Practices in Bundi District of Rajasthan. Chem. Sci.Rev.Lett. 6(22): 995-999.

Grover, D.K. and Kumar,S. 2012. Economics of production, processing and marketing of fodder crops in India (consolidated report) AERC STUDY No. 29 AgroEconomic Research Centre Department of Economics and Sociology Punjab Agricultural University Ludhiana, 180.

Hundal, J. S., Singh, U., Singh, N., Kansal, S. K. and Bhatti, J. S. 2016. Impact of training on knowledge level of goat farmers in Punjab. Haryana Veterinarian. 55(1): 47-49.

Ingle, P.O. and Kubde, N. R. 1995. Evaluation of Krishi Vigyan Kendra programmes. Agriculture Extension Review. 7(2): 3-6.

Kalsariya, B.N., Bharad, N. D. and Jadeja, M.K. 2015. Impact of Training Programme in Terms of Gain in Knowledge for Sustainable Agriculture. Guj. J. Ext. Edu. 26(2): 154-157.

Kasrija, R. and Verma, H.K. 2014. Practices affecting reproduction (PAR) score of dairy farmers in western region of Punjab. Indian Journal of Animal Reproduction. 35(2):42- 46.

Kaushal, S., Wadhwa, M., Hundal, J.S., Kaur, K. and Bakshi, M.P.S. 2011. Nutritional status of dairy animals of undulating plain zone of Punjab. Animal Nutrition and Feed Technology.11: 277-284.

Kiptot, E., Franzel, S., Sinja, J., Nang’ole, E. 2015. Preference and adoption of livestock feed practices among farmers in dairy management groups in Kenya. ICRAF Working Paper No. 208. Nairobi, World Agroforestry Centre. DOI: http://dx.doi.org/10.5716/WP15 675.PDF

Lokhande, J.P. 2009. A comprehensive study of scientific temperament among dairy farmers of Karnal district (Haryana), M.Sc. Thesis, NDRI, Karnal, Haryana, India.

Maroo, K. 2005. Knowledge and Adoption of Improved Dairy Management Practices by women dairy farmers in Dharwad district, MSc Thesis, College Of Agriculture, Dharwad University Of Agricultural Sciences, Dharwad - 580 005.

Mathialagan, P. and Kumarasan, G. 2015. Farm women participatory on-farm trial (OFT) on prevention and control of mastitis in Dairy cattle. Ind. J. Vet. \&Anim. Sci. Res. 44(2): 110-115.

Meena, B.S., Singh, A. K., Chauhan, J. and Sankhala, G. 2009. Farmers' Knowledge on Feeding Practices of Dairy Animals in Jhansi District Indian Res. J. Ext. Edu. 9(1): 28- 31.

Meena, M. S., Singh, K. M., Malik, B. S., Meena, B. S. and Kanwat, M. 2012. Knowledge Index for Measuring Knowledge and Adopting Scientific Methods in Treatment of Reproductive Problems of Dairy Animals. Journal of Agricultural Science. 4(10): 81-88.

Nampanya, S., Rast, L., Khounsy, S. and Windsor, P. A. 2010.Assessment of Farmer Knowledge of Large Ruminant Health and Production in Developing Village-Level Biosecurity in Northern Lao PDR. Transboundary and 
Emerging Diseases. https://www. researchgate.net/publication/47620416

Nirmala, T. V., Sharma G.R.K., Subrahmanyeswari, B. and Suresh, J. 2016.Effectiveness of multimedia modules in knowledge gain and retention among dairy farmers. International Journal of Science, Environment and Technology. 5(2): 438-444.

Sasane, G.K., Khule, R. P. and Jagdale, U. D. 2013. Knowledge level of farmers about improved dairy management practices. Int. J. Extn. Edu.9: 43-46.

Sathiadas, R., Noble, D., Inamanuel, S., Jayon, K. N. and Sadanandan, S. 2001.Adoption level of scientific dairy farming practices by IVLP farmers in the coastal agro ecosystem of Kerala. Indian Journal of Scientific Research. 44(3): 240-250.

Senthilkumar, K., Daisy, M., Kumaravel, V. and Mohan, B. 2014.Impact of KVK training on scientific method of goat rearing and feeding management of azolla. International Journal of Science, Environment and Technolog., 3(6): 2287-2292.

Sharma, G.R.K. 2016.Effectiveness of Multimedia Modules on Dissemination of Knowledge among the Dairy Farmers. Journal of Research Development. $4(1)$ http://dx.doi.org/10.4172/jrd.1000142.

Singh, K. and Prasad, C.S.2002. In Birthal, P. and Rao P. (eds). 2002. Technology options for sustainable livestock production in India: proceedings of the Workshop on Documentation, Adoption, and Impact of Livestock Technologies in India, 18-19 Jan 2001, ICRISAT-Patancheru, India. New Delhi 110 012, India and Patancheru 502 324, Andhra Pradesh, India: National Centre for Agricultural Economics and Policy Research and International Crops Research Institute for the Semi-Arid Tropics. 220 pp.

Singh, K. and Schiere, J.B. 1994. On-farm research for testing of appropriate technologies in crop livestock production system, Technical Bulletin No. 3.New Delhi, India: ICAR-BAIFBIOCON-Winrock International; 1994.

Tóth, P. 2014. The role of individual differences in learning land restoration training programme. Acta Polytechnica Hungarica. 11(4): 183-197.

Williams. B., Myerson, J. and Hale, S. 2008. Individual differences, intelligence, and behavior analysis. Journal of Experimental Analysis of Behaviour. 90(2): 219-231.

Wilson, R. 2007.Status and prospects for livestock production in the Lao People's democratic Republic. Trop. Anim. Health.Prod.39: 443-452.

Yikii, F. 2009. Research approaches for maximising knowledge gain and adoption. Land Restoration Training Programme Final project 2009 Keldnaholt, 112 Reykjavík, Iceland 37.

\section{How to cite this article:}

Aparna, Suresh Kumar Kansal, Harish KumarVerma, Jaspal Singh Hundal, Parminder Singh and Jaswinder Singh. 2018. Knowledge Index of Farmers about Animal Feed Technologies during Various Training Programmes at Veterinary Varsity in Punjab, India. Int.J.Curr.Microbiol.App.Sci. 7(04): 366-377. doi: https://doi.org/10.20546/ijcmas.2018.704.042 